\title{
PENGARUH PENERAPAN METODE OUTDOOR LEARNING BERBASIS KELOMPOK TERHADAP HASIL BELAJAR IPS DI SDN
}

\author{
Karmila \\ Alumni Mahasiswa Pendidikan Dasar \\ Program Studi Administrasi Pendidikan PPs UNM \\ e-mail: karmilaiskandar124@yahoo.com
}

\begin{abstract}
Purpose of this study were (i) How does outdoor learning methods overview of the application of the group based on the results of the fourth grade social studies at the Teachers' Training College Maccini SDN Makassar (ii) Is there any influence of outdoor learning method based on learning outcomes IPS group of fourth grade in SDN KIP Maccini Makassar. This research is a quantitative type of true experimental research. Techniques of collecting data through tests of student learning outcomes. The population in this study is the fourth grade students of the school year 2014/2015 The samples in this study were taken from two schools dikecamatan Makassar SDN KIP Maccini and SD Instruction Maccini ie the whole fourth grade students numbered seventy people from the large number of the population. The result showed that (i) description of the application of methods of outdoor learning group based on the results of social studies class IV in SDN Teachers' Training College Maccini Makassar (ii) There is the effect of the application of methods of outdoor learning group based on learning outcomes IPS fourth grade students at SDN KIP Maccini Makassar.
\end{abstract}

\section{Keywords: Discussion Carrousel Method, Learning Interest, Science Learning}

\begin{abstract}
ABSTRAK
Tujuan penelitian ini adalah untuk mengetahui (i) Gambaran penerapan metode outdoor learning berbasis kelompok terhadap hasil belajar IPS kelas IV di SDN KIP Maccini Makassar (ii) Gambaran prestasi belajar kelompok kontrol sebelum dan sesudah diajar dengan metode konvensioanal dalam mata pelajaran IPS (iii) Gambaran prestasi belajar kelompok eksperimen sebelum dan sesudah diajar dengan metode outdoor learning berbasis kelompok dalam mata pelajaran (iv) Perbedaan hasil belajar antara kelompok eksperimen yang menggunakam metode outdoor learning berbasis kelompok dan kelompok kontrol yang menggunakan metode konvensional IPS. Prosedur eksperimen ini dikategorikan kedalam kelompok eksperimen metode pembelajaran outdoor learning berbasis kelompok dan kelompok kontrol metode pembelajaran konvensional. Analisis data hasil penelitian ini dianalisis dengan statistika deskriptif dan teknik analisis statistik infrensial. Hasil penelitian (i) Pelaksanaan pembelajaran metode outdoor learning berbasis kelompok sebelum berangkat ke lapangan siswa bersama seluruh kelompoknya diberi penjelasan yang akan dikerjakan di lokasi, siswa berpencar menurut kelompoknya kemudian melakukan observasi, secara berkelompok mereka melaporkan hasil pengamatannya (ii) prestasi belajar kelompok kontrol dan eksperimen sebelum dan sesudah diberi perlakuan dikategorikan cukup dan baik sedangkan kelompok eksperimen yaitu baik dan sangat baik (iii) uji hipotesis yaitu menggunakan uji t
\end{abstract}

Kata Kunci: metode outdoor learning, tujuan belajar, ilmu

\section{PENDAHULUAN}

Pendidikan merupakan suatu usaha sadar dan terencana untuk mewujudkan suasana belajar dan proses pembelajaran agar peserta didik mengalami perubahan tingkah laku sehingga mampu secara aktif mengembangkan potensi dirinya untuk memiliki kekuatan spiritual 
keagamaan, pengendalian diri, kepribadian, kecerdasan, akhlak mulia, serta keterampilan yang diperlukan dirinya, masyarakat, bangsa, dan negara.

Dinamika perkembangan ilmu pengetahuan dalam era industri dan informasi dewasa ini membuat situasi dunia menjadi sukar diprediksi. IPS dengan hakikatnya sebagai ilmu yang terstruktur dan sistematis, sebagai suatu kegiatan manusia melalui proses yang aktif, dan dinamis, serta sebagai ilmu yang mengembangkan sikap berpikir kritis, objektif, dan terbuka menjadi sangat penting untuk dimiliki peserta didik dalam menghadapi era perkembangan sosial dimasyarakat.

Mata pelajaran IPS perlu diberikan kepada semua peserta didik mulai dari sekolah dasar untuk membekali peserta didik dengan kemampuan berpikir logis, analisis, sistematis, kritis, dan kreatif, serta kemampuan bekerja sama khususnya dalam lingkup sosial masyarakatnya.

Menurut Soedjadi (1994) bahwa salah satu ilmu dasar yang mempunyai peranan penting dalam pembelajaran adalah IPS, baik aspek terapan maupun penalarannya. Hal ini berarti bahwa IPS merupakan salah satu ilmu dasar yang memegang peranan penting dalam membantu siswa melihat fenomena sosial yang terjadi disekitarnya, karena IPS merupakan sarana berpikir untuk menumbuh kembangkan cara berpikir logis, sistematis dan kritis. IPS juga memberikan bekal kepada peserta didik untuk dapat menerapkan IPS diberbagai keperluan, antara lain dalam kehidupan sehari-hari. Namun kenyataannya, prestasi belajar IPS peserta didik masih sangat rendah.

Fenomena yang terjadi di lapangan menunjukkan bahwa rendahnya prestasi belajar IPS siswa karena penggunaan metode belajar konvensional yang dilakukan oleh guru tersebut. Maka melihat gambaran tersebut peneliti ingin melihat sejauh mana pengaruh penerapan metode outdoor learning berbasis kelompok terhadap hasil belajar IPS di SD KIP Maccini kota Makassar.

Fakta di lapangan menunjukkan masih ada sebagian siswa yang kurang memahami konsep yang ada pada pembelajaran IPS. Berdasarkan hasil pengamatan tanggal 15 Januari 2015 dan informasi yang diperoleh dari wali kelas IV di SD KIP Maccini Makassar. Peneliti mendapatkan informasi bahwa motivasi dan hasil belajar IPS kurang, nilai rata-rata 6,2 atau 62\% di bawah nilai ketuntasan yang diharapkan yakni 7,0 atau $70 \%$. Fakta inilah yang kemudian dijadikan sebagai salah satu bahan pertimbangan bagi peneliti untuk memilih SDN KIP Maccini Makassar sebagai lokasi penelitian hal ini disebabkan karena peserta didik kurang memiliki motivasi untuk mempelajari hal-hal yang abstrak. Sekedar menghafal saja. Kondisi dasar yang lebih menonjol adalah proses belajar diabatasi oleh ruang kelas, berlangsung didalam kelas (in door learning). sehingga sulit menggugah wahana berpikir kreatif siswa sehingga peserta didik memiliki keterbatasan imajinasi dan mendapatkan pemahaman terbatas yang kurang mampu menghubungkan pengalaman yang sudah ada dengan materi yang akan diajarkan.

Berdasarkan realita di atas sehingga memicu ketuntasan belajar dalam kategori rendah yang tercermin pula dalam prestasi belajar karena penerapannya berpusat di dalam kelas saja sehingga berdampak motivasi belajarnya juga rendah.

Mengacu pada observasi awal yang dilakukan peneliti maka penggunaan metode dalam pembelajaran berbasis outdoor learning berbasis kelompok dianggap penting yang memerlukan rancangan pembelajaran yang efektif sesuai materi pembelajaran. Peneliti ingin melihat pengaruh penerapan metode outdoor learning berbasis kelompok terhadap hasil belajar IPS di Sekolah Dasar Macini Makassar

Berdasarkan landasan penelitian inilah, peneliti ingin mengetahui lebih jauh tentang "Pengaruh Penerapan Metode Outdoor Learning Berbasis Kelompok terhadap Hasil Belajar IPS di SDN KIP Maccini Makassar.”

Berdasarkan latar belakang yang telah diuraikan maka pertanyaan penelitian adalah: (1) Bagaimanakah gambaran penerapan metode outdoor learning berbasis kelompok terhadap hasil belajar IPS kelas IV di SDN KIP Maccini Makassar? (2) Bagaimanakah gambaran prestasi belajar kelompok kontrol sebelum dan sesudah diajar dengan metode konvensional dalam mata pelajaran IPS kelas IV di SDN KIP Maccini Makassar? (3) Bagaimanakah gambaran prestasi belajar kelompok eksperimen sebelum dan sesudah diajar dengan metode konvensional dalam mata pelajaran IPS kelas IV di SDN KIP Maccini Makassar? (4) Apakah ada perbedaan hasil belajar antara kelompok yang menggunakam metode outdoor learning berbasis 
kelompok dibandingkan metode konvension IPS kelas IV di SDN KIP Maccini Makassar?

Menurut Husamah (2013:19)

menyatakan, outdoor learning merupakan aktivitas luar sekolah yang berisi kegiatan di luar kelas/sekolah dan di alam bebas lainnya. Dimana guru merencanakan untuk menyelenggarakan pembelajaran di luar kelas, memberi salam, membagi siswa dalam kelompok, guru memberi motivasi, memberi panduan belajar kepada masing-masing kelompok, guru memberi penjelasan cara kerja kelompok, masing-masing kelompok berpencar pada lokasi untuk melakukan pengamatan dan diberi waktu, guru membimbing siswa selama pengamatan di lapangan, selesai pengamatan siswa diarahkan berkumpul kembali untuk mendiskusikan hasil pengamatannya, guru memandu diskusi dan siswa diberi kesempatan persentasikan hasil diskusinya masing-masing kelompok dan kelompok lain diberi waktu untuk menanggapi. Pembelajaran di luar ruangan dapat membuat siswa lebih dapat mengenal alam sekitar sebagai media untuk belajar siswa.

Menurut Nawawi (1981: 39) hasil belajar adalah perubahan-perubahan yang terjadi pada diri siswa, baik yang menyangkut aspek kognitif, afektif, dan psikomotor sebagai hasil dari kegiatan belajar. Untuk mengetahui hasil belajar yang dicapai telah sesuai dengan tujuan yang dikehendaki dapat diketahui melalui evaluasi. Dikemukakan oleh Sunal (1993: 94) bahwa evaluasi merupakan proses penggunaan informasi untuk membuat pertimbangan seberapa efektif suatu program telah memenuhi kebutuhan siswa. Selain itu dilakukan evaluasi atau penilaian ini dapat dijadikan feedback atau tindak siswa. Kemajuan prestasi belajar siswa tidak saja diukur dari tingkat penguasaan ilmu pengetahuan, tetapi juga sikap dan keterampilan. Penilaian hasil belajar siswa mencakup segala hal yang dipelajari di sekolah, baik itu menyangkut pengetahuan, sikap, dan keterampilan yang berkaitan dengan mata pelajaran yang diberikan kepada siswa. Hasil belajar seringkali digunakan sebagai ukuran untuk mengetahui seberapa jauh seseorang menguasai bahan yang sudah diajarkan. Untuk mengaktualisasikan hasil belajar tersebut diperlukan serangkaian pengukuran menggunakan alat evaluasi yang baik dan memenuhi syarat.

Pada prinsipnya tujuan yang ingin dicapai di dalam penelitian ini adalah untuk mengetahui: (1) Gambaran penerapan metode outdoor learning berbasis kelompok terhadap hasil belajar IPS kelas IV di SDN KIP Maccini Makassar. (2) Gambaran prestasi belajar kelompok kontrol sebelum dan sesudah diajar dengan metode konvensioanal dalam mata pelajaran IPS kelas IV SDN KIP Maccini Makassar. (3) Gambaran prestasi belajar kelompok eksperimen sebelum dan sesudah diajar dengan metode outdoor learning berbasis kelompok dalam mata pelajaran IPS kelas IV SDN KIP Maccini Makassar. (4) Perbedaan hasil belajar antara kelompok eksperimen yang menggunakam metode outdoor learning berbasis kelompok dan kelompok kontrol yang menggunakan metode konvensional IPS kelas IV di SDN KIP Maccini Makassar.

Hipotesis penelitian ini adalah: terdapat perbedaan hasil belajar antara siswa kelompok eksperimen yang menggunakan metode pembelajar outdoor learning berbasis kelompok dengan siswa kelompok control yang menggunakan metode konvensional dimana siswa kelompok eksperimen hasil belajarnya lebih baik disbanding dengan siswa kelompok control.

\section{METODE PENELITIAN}

Jenis penilitian ini adalah penelitian eksperimen, menggunakan true eksperimental design yang bertujuan untuk mengetahui pengaruh penerapan metode outdoor learning berbasis kelompok terhadap hasil belajar IPS siswa kelas IV di SDN KIP Maccini Makassar. Populasi dalam penelitian ini adalah seluruh siswa Sekolah Dasar di Kelas IV SDN KIP Macini Kecamatan Ujung Pandang Kota Makassar semester ganjil Tahun Ajaran 2015.

Pengambilan sampel dilakukan dengan cara cluster random sampling atau sampel acak kelompok. Cluster random sampling adalah teknik kelompok atau rumpun, dilakukan dengan jalan memilih sampel yang didasarkan pada kelompoknya bukan pada individunya. Dalam teknik ini semua individu dalam populasi baik secara sendiri-sendiri atau bersama-sama diberikan kesempatan yang sama untuk dipilih menjadi kelas eksperimen atau kelas kontrol. Dari kedua kelas untuk menentukan kelas eksperimen dan kelas kontrol dilakukan dengan cara random (acak). Dilihat dari semua siswa di kelas A dan B dipakai dalam penelitian maka hal 
ini dinamakan purposif sampling.Dengan demikian sampel dalam penelitian ini masingmasing berjumlah 35 orang.

Teknik pengumpulan data dan instrument penelitian yang digunakan dalam penelitian ini berupa evaluasi formatif dan sumatif hasil belajar IPS serta lembar observasi guru dan siswa . Lembar observasi ini digunakan untuk mengukur atau menilai proses belajar, yaitu gambaran pelaksanaan penggunaan metode outdoor learning berbasis kelompok dan tingkah laku siswa pada saat pembelajaran. Pengisian lembar observasi ini dilakukan dengan cara memberikan tanda cek list $(\sqrt{ })$ pada kolom nilai pengamatan observasi. Observasi dalam penelitian ini hasil pengamatannya diberi nilai atau disediakan nilai dengan angka 4, 3, 2, 1 yang bermakna sebagai skala nilai.

Data yang diperoleh dari sampel penelitian berupa data kuantitatif .Data tersebut dianalisis dengan statistika deskriptif dan teknik analisis statistik infrensial.Statistika deskriptif adalah statistika yang berfungsi mendeskripsikan atau memberikan gambaran terhadap objek yang diteliti melalui data sampel atau populasi sebagaimana adanya, tanpa melakukan analisis dan membuat kesimpulan yang berlaku untuk umum (Sugiyono, 2010:207). Teknik analisis inferensial adalah teknik statistik yang digunakan untuk menganalisis data sampel dan hasilnya diberlakukan untuk populasi (Sugiyono, 2010: 209).

Untuk analisis statistik inferensial digunakan uji prasarat yaitu uji normalitas dan uji homogenitas. Setelah datanya normal dan homogen baru dilakukan uji t.

\section{HASIL DAN PEMBAHASAN}

\section{Hasil}

1. Gambaran Penerapan Metode Outdoor Learning Berbasis Kelompok Terhadap Hasil Belajar IPS Kelas IV di SDN KIP Maccini Makassar

Outdoor learning merupakan aktivitas luar sekolah yang berisi kegiatan di luar kelas/sekolah dan di alam bebas lainnya. Berdasarkan pemahaman tersebut maka keefektifan pembelajaran dapat dilihat dari tahapan proses outdoor learning yaitu guru merencanakan untuk menyelenggarakan pembelajaran di luar kelas, guru memberi salam, guru membagi siswa dalam kelompok, guru memberi motivasi, guru memberi panduan belajar kepada masing-masing kelompok, guru memberi penjelasan cara kerja kelompok, masing-masing kelompok berpencar pada lokasi untuk melakukan pengamatan dan diberi waktu, guru membimbing siswa selama pengamatan di lapangan, selesai pengamatan siswa diarahkan berkumpul kembali untuk mendiskusikan hasil pengamatannya, guru memandu diskusi dan siswa diberi kesempatan persentasikan hasil diskusinya masing-masing kelompok dan kelompok lain diberi waktu untuk menanggapi.

2. Gambaran Hasil Belajar IPS kelas IV di SDN KIP Maccini Makassar Sebelum Penerapan Metode Outdoor Learning Berbasis Kelompok

Untuk mendapatkan gambaran rata - rata hasil belajar siswa, besar standar deviasi hasil belajar IPS sebelum perlakuan, diperoleh berdasarkan penilaian kemampuan belajar IPS sebelum perlakuan, dapat dilihat sebagai berikut

\section{a. Hasil Data Pre Test Kelas Kontrol}

Dilihat dari hasil data Pre Test Kelas Eksperimen secara keseluruhan, dari rentangan skor 53 sampai dengan 87, di dapat hasil ratarata sebesar 73,143 dan simpangan baku sebesar 9,127 . Berdasarkan data pre tes dapat dilihat bahwa, terdapat 17 orang atau $48 \%$ yang memperoleh skor di bawah rata-rata, 9 orang atau $26 \%$ berada pada nilai rata-rata, dan 9 orang lainnya atau $26 \%$ mendapatkan nilai di atas ratarata lebih rincinya 2 orang kategori rendah, 3 orang kategori sedang, 26 kategori tinggi dan 4 orang kategori sangat tinggi

\section{b. Hasil Data Post Test Kelas Kontrol}

Dilihat dari hasil data Pre Test Kelas Kontrol secara keseluruhan, dari rentangan skor 60 sampai dengan 93, di dapat hasil rata-rata sebesar 78,686 dan simpangan baku sebesar 9,1323 . Berdasarkan data pre tes dapat dilihat bahwa dapat dilihat bahwa, terdapat 5 orang atau $15 \%$ yang memperoleh skor di bawah rata-rata, 16 orang atau $46 \%$ berada pada nilai rata-rata, dan 14 orang lainnya atau $40 \%$ mendapatkan nilai di atas rata-rata dan lebih terperincinya 3 orang dalam kategori sedang, 20 orang dalam 
kategori tinggi, dan 12 orang dalam kategori sangat tinggi

3. Gambaran Hasil Belajar IPS Kelas IV di SD KIP Maccini Makassar Setelah Penerapan Metode Outdoor Learning Berbasis Kelompok

Untuk mendapatkan gambaran rata-rata hasil belajar siswa, besar standar deviasi hasil belajar IPS setelah perlakuan, diperoleh berdasarkan penilaian kemampuan belajar IPS setelah perlakuan, dapat dilihat sebagai berikut :

\section{a. Hasil Data Pre Test Kelas Eksperimen}

Dilihat dari hasil data Post Test Kelas Eksperimen secara keseluruhan, dari rentangan skor 60 sampai dengan 93, di dapat hasil ratarata sebesar 76,171 dan simpangan baku sebesar 9,9217 . Berdasarkan data pre tes dapat dilihat bahwa terdapat 9 orang atau $26 \%$ yang memperoleh skor di bawah rata-rata, 9 orang atau 26\% berada pada nilai rata-rata, dan 17 orang lainnya atau $49 \%$ mendapatkan nilai di atas rata-rata dan lebih detail 6 orang dalam kategori sedang, 20 orang dalam kategori tinggi, dan 9 orang dalam kategori sangat tinggi.

\section{b. Hasil Data Post Test Kelas Eksperimen}

Dilihat dari hasil data Post Test Kelas Kontrol secara keseluruhan, dari rentangan skor 53 sampai dengan 87, di dapat hasil rata-rata sebesar 73,143 dan simpangan baku sebesar 9,127 . Berdasarkan data pre tes dapat dilihat bahwa, terdapat 13 orang atau 38\% yang memperoleh skor di bawah rata-rata, 8 orang atau $23 \%$ berada pada nilai rata-rata, dan 14 orang lainnya atau $40 \%$ mendapatkan nilai di atas rata-rata dan lebih detailnya 9 orang dalam kategori tinggi dan 26 orang dalam kategori sangat tinggi.

\section{Perbedaan Hasil Belajar dengan Metode Outdoor Learning Berbasis Kelompok dengan Metode Konvensional dalam Mata Pelajaran IPS kelas IV di SDN KIP Maccini Makassar}

Berdasarkan hasil perhitungan Uji Perbedaan Dua Rata-rata (Uji-t) dapat diketahui bahwa nilai hasil pengujian hipotesis yang disajikan secara keseluruhan bahwa $t_{\text {hitung }}=6,51$. bahwa perhitungan Uji-t menunjukkan hasil perhitungan tentang perbedaan keefektifan antara kedua model pembelajaran secara keseluruhan bahwa $\mathrm{t}_{\text {hitung }}=6,51>\mathrm{t}_{\text {abel }}=1,99$ pada taraf Signifikan $\alpha=0.05$, dengan demikian $\mathrm{H}_{0}$ ditolak dan hipotesis alternatif $\mathrm{H}_{1}$ diterima. Dengan demikian terdapat perbedaan yang signifikan skor hasil belajar IPS sebelum dan sesudah pembelajaran dengan metode outdoor learning berbasis kelompok. Jadi hal ini berarti bahwa pembelajaran dengan metode outdoor learning berbasis kelompok berpengaruh terhadap terhadap hasil belajar IPS kelas IV di SDN IKIP Maccini Makassar.

\section{Pembahasan}

Meninjau dari tahapan outdoor learning berbasis kelompok maka dipaparkan hasil penelitian dan analisis data, pada saat evaluasi awal atau pre observasi yaitu kegiatan sebelum diberikan perlakuan dengan metode outdoor learning berbasis kelompok diperoleh nilai rata-rata belajar IPS sebesar 76,17. Jika dikategorikan dalam pengkategorian hasil belajar IPS berada pada kategori tinggi. Sedangkan pada tahap evaluasi akhir atau post observasi yaitu setelah diberikan perlakuan dengan metode outdoor learning berbasis kelompok, diperoleh tingkat hasil belajar peserta didik dengan nilai rata-rata sebesar 89,34. Hal ini menunjukkan terdapat peningkatan hasil belajar peserta didik dari sebelumnya. Dengan demikian pengkategorian hasil belajar IPS berada pada kategori sangat tinggi. Berdasarkan hal tersebut, maka dapat dinyatakan bahwa hasil belajar siswa kelas IV Sekolah Dasar setelah diberikan perlakuan dengan metode outdoor learning berbasis kelompok meningkat dari hasil sebelumnya.

Dari hasil pengujian hipotesis dengan uji $t$ diperoleh nilai t hitung sebesar $\mathrm{t}_{\mathrm{o}}=6,51$. Jika dibandingkan dengan nilai $t$ tabel pada derajat kebebasan 68 dengan taraf signifikan 5\% maka diperoleh $\mathrm{t}$ tabel sebesar $\mathrm{t}_{\alpha}=1,99$ maka dapat dinyatakan bahwa $t_{0}>t_{\alpha}=6,51>1,99$. Hal ini menunjukkan bahwa $\mathrm{H}_{0}$ pada penelitian ini ditolak. Dari hasil ini, maka dapat disimpulkan bahwa diberikan perlakuan dengan metode outdoor learning berbasis kelompok dapat meningkatkan hasil belajar IPS peserta didik di kelas IV di SDN IKIP Maccini Makassar. 
Setelah dilakukan pembelajaran menggunakan metode outdoor learning berbasis kelompok pada kelas eksperimen dan kelompok kontrol dengan menggunakan pembelajaran konvensional terlihat bahwa hasil belajar kedua kelompok tersebut berbeda secara nyata. Hal ini ditunjukan dengan hasil uji $t_{\text {hitung }}$ sebesar 5,142 dengan nilai $t_{\text {tabel }}=1,67$. Karena $t_{\text {hitung }}>t_{\text {tabel }}$ maka $\mathrm{H}_{0}$ ditolak. Dengan kata lain ada pengaruh positif terhadap hasil belajar pada kelas eksperimen dan kelas kontrol.

Dari hasil penghitungan terlihat bahwa hasil belajar kelas eksperimen lebih baik dari pada kelas kontrol dengan nilai rata-rata kelas eksperimen sebesar 89,34 dan kelas kontrol sebesar 78,68. Dengan demikian pembelajaran melalui metode outdoor learning berbasis kelompok berpengaruh positif terhadap hasil belajar IPS di Kelas IV SDN KIP Maccini Makassar.

Perbedaan rata-rata hasil belajar peserta didik antara kelas eksperimen dan kelas kontrol tersebut disebabkan oleh adanya perbedaan perlakuan. Pada kelas eksperimen yang diberi pembelajaran melalui metode outdoor learning berbasis kelompok. Hal tersebut dapat memberikan pengaruh positif karena outdoor learning adalah suatu kegiatan di luar kelas yang menjadikan pembelajaran di luar kelas menarik dan menyenangkan, dapat dilakukan dimanapun dengan menekankan proses belajar berdasarkan fakta nyata dengan cara materi pembelajarannya secara langsung dialami oleh peserta didik melalui kegiatan pembelajaran secara langsung dengan harapan peserta didik lebih menumbuhkan makna dan kesan dalam memori jangka panjangnya. Sehingga dapat disimpulkan kelompok siswa yang mendapatkan pembelajaran di luar kelas memperoleh nilai hasil belajar IPS lebih tinggi dibandingkan kelompok siswa yang mendapatkan pembelajaran di dalam kelas.

Dengan menggunakan tahapan outdoor learning berbasis kelompok pada pertemuan pertama dan kedua masuk dalam kategori cukup dan selanjutnya pelaksanaan kegiatan belajar mengajar guru dan siswa dalam penerapan outdoor learning pada pertemuan ke tiga dan empat berada pada kategori baik dan sangat baik maka dapat disimpulkan bahwa terjadi peningkatan dalam proses pembelajaran yang menggunakan metode outdoor learning. Hal ini dilihat dari tercapainya hasil belajar belajar IPS dengan menggunakan metode outdoor learning berbasis kelompok berpengaruh positif terhadap hasil belajar IPS di Kelas IV SDN KIP Maccini Makassar.

Hasil yang diperoleh pada penelitian ini telah sesuai dengan teori yang telah dikemukakan oleh Sunal (1993: 94) untuk mengetahui hasil belajar yang dicapai telah sesuai dengan tujuan yang dikehendaki dapat diketahui melalui hasil belajar IPS. Pengertian tentang hasil belajar sebagaimana diuraikan di atas dipertegas oleh Nawawi (dalam Brahim,2007:39) yang menyatakan bahwa hasil belajar dapat diartikan sebagai tingkat keberhasilan siswa dalam mempelajari materi pelajaran di sekolah yang dinyatakan dalam skor yang diperoleh dari hasil tes mengenal sejumlah materi pelajaran tertentu. Dengan demikian, semakin jelaslah bahwa teori tersebut menyatakan bahwa hasil belajar yang dicapai telah sesuai dengan tujuan yang dicapai.

\section{SIMPULAN DAN SARAN}

Dalam pembelajaran dapat dilihat dari tahapan proses outdoor learning yaitu : (1) Dalam pembelajaran dapat dilihat dari tahapan proses outdoor learning yaitu guru merencanakan untuk menyelenggarakan pembelajaran di luar kelas, guru memberi salam, guru membagi siswa dalam kelompok, guru memberi motivasi, guru memberi panduan belajar kepada masing-masing kelompok, guru memberi penjelasan cara kerja kelompok, masing-masing kelompok berpencar pada lokasi untuk melakukan pengamatan dan diberi waktu, guru membimbing siswa selama pengamatan di lapangan, selesai pengamatan siswa diarahkan berkumpul kembali untuk mendiskusikan hasil pengamatannya, guru memandu diskusi dan siswa diberi kesempatan persentasikan hasil diskusinya masing-masing kelompok dan kelompok lain diberi waktu untuk menanggapi. (2) Hasil pre tes kelompok kontrol sebelum diajar dengan metode konvensional dikategorikan tinggi Sedangkan setelah diajar dengan menggunakan metode konvensional dikategorikan baik. (3) Hasil pre tes kelompok eksperimen sebelum diajar dengan metode outdoor learning berbasis kelompok dikategorikan tinggi sedangkan setelah diberikan perlakuan dikategorikan sangat tinggi.(4) Terdapat perbedaan yang signifikan antara hasil 
belajar kelompok eksperimen yang menggunakan metode outdoor learning berbasis kelompok dan hasil belajar kelompok kontrol yang menggunakan metode konvensional, dimana hasil belajar kelompok eksperimen jauh lebih tinggi. Ini berarti bahwa outdoor learning berbasis kelompok berpengaruh positif terhadap prestasi belajar siswa.

Berdasarkan kesimpulan penelitian yang telah dikemukakan sebelumnya, maka dapatlah diajukan saran dalam penelitian ini, sebagai berikut : (1) Diharapkan kepada guru agar mampu mengembangkan dan menerapkan menerapan metode outdoor learning berbasis kelompok dengan cara membawa siswanya belajar di luar kelas dalam upaya peningkatan hasil belajar siswa. (2) Sebagai tindak lanjut penerapan, pada saat proses pembelajaran diharapkan guru untuk lebih mengawasi dan mengontrol serta membimbing siswa dalam bekerja kelompok di luar kelas. (3) Kepala Sekolah diharapkan mengawasi dan mengarahkan guru yang memiliki masalah pembelajaran yang relatif sama dapat menerapkan pembelajaran dengan metode outdoor learning berbasis kelompok.

\section{DAFTAR RUJUKAN}

Husamah. 2013. Pembelajaran Luar Kelas Outdoor Learning. Jakarta: Prestasi Pustaka

Nawawi, Hadari. 1981. Pengaruh Hubungan Manusiawi di Kalangan Murid Terhadap Prestasi Belajar di Sekolah. Yogyakarta. IKIP Yogyakarta

Sunal, Chyntia S\&Hass, Mary E (1993). Social Studies and ElementaryMiddle School Students. USA: Holt Rinehart and Windston, Inc.

Sugiono. 2010. Metode Penelitian Pendidikan

Pendekatan Kuantitatif, kualitatif dan

$R \& D$. Bandung: Alfabeta 